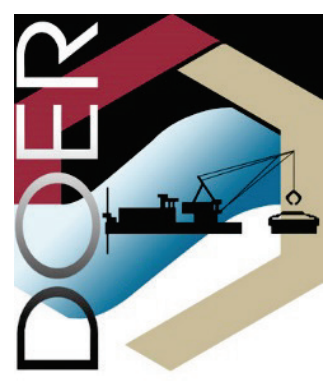

ERDC TN-DOER-R24

September 2016

\title{
Dredged Material Evaluations: Review of Zooplankton Toxicity Test Methods for Marine Water Quality Evaluations
}

by Alan J Kennedy, Guilherme Lotufo, Jennifer G. Laird, and J. Daniel Farrar

PURPOSE: The first objective of this Dredging Operations and Engineering (DOER) technical note is to summarize currently available estuarine and marine water-only zooplankton toxicity test methods that may be suitable for use (with or without modifications) in dredging evaluations that are being conducted under the Marine Protection Research and Sanctuaries Act (103 evaluations). The second objective is to identify additional zooplankton species that are available commercially but do not have established test methods. Development of toxicity test methods should be considered for these marine zooplankton species.

BACKGROUND: Dredging of ports and harbors is necessary to maintain navigable waterways. However, large volumes of dredged sediment or dredged material (DM) must be managed. Federal regulations require the physical, chemical, and toxicological evaluation of DM to determine if it is suitable for unrestricted open water placement, beneficial use, or if management strategies are necessary. Open water placement of DM into inland water bodies or coastal areas inland of the national baseline is regulated under the Clean Water Act (CWA). Open water placement into the ocean is regulated under the Marine Protection Research and Sanctuaries Act (MPRSA). Toxicological evaluations of DM involve testing the potential for short-term impacts of the DM while settling through the water column (elutriate toxicity tests), and long-term toxicity (whole sediment toxicity tests) and accumulation of contaminants of concern into biological tissue (bioaccumulation tests) after sediment settles at the placement site. Technical guidance for performing DM evaluations under MPRSA and CWA is provided in the Ocean Testing Manual (USEPA/USACE 1991) and Inland Testing Manual (USEPA/USACE 1998), respectively. While these documents provide valuable information, including toxicological test methods, they require updating.

Sediment elutriates are prepared according to guidance (USEPA/USACE 1991; 1998) by mixing sediment and site water and allowing settling for prescribed periods. Additional detail on the creation of sediment elutriates for toxicity testing can be found in Kennedy et al. (2015). Generally, recommended species for elutriate toxicity tests are fish, invertebrates (crustaceans), and zooplankton. Freshwater evaluations (following CWA regulations) use standard test organisms and methods covering fish and zooplankton taxa (USEPA 2002). The MPRSA requires greater specificity on the type and number of test species used in testing. According to 40 CFR §227.27 (Limiting Permissible Concentration 2012), "appropriate sensitive marine organisms means at least one species each representative of phytoplankton or zooplankton, crustacean or mollusk, and fish species chosen from 
among the most sensitive species documented in the scientific literature or accepted by EPA as being reliable test organisms to determine the anticipated impact of the wastes on the ecosystem at the disposal site". This effectively requires three elutriate toxicity test methods to be employed for each evaluation conducted under MPRSA. For additional information on how these biological tests relate to different compartments of the placement site, with a heavy focus on the conduct of water column toxicity evaluations of DM, see Kennedy et al. (2015).

TOXICITY TESTS USING PLANKTONIC EMBRYOS: The American Society for Testing and Materials International (ASTM) has produced standardized toxicity tests for echinoderm (ASTM E1563-98[2004]) and bivalve (mussels, oysters) embryo development (ASTM E724-98[2004]); these test methods are currently being used as zooplankton tests for MPRSA evaluations in some regions. The organisms used in these test methods are not planktonic for most of their life cycles (juveniles and adults are benthic). Only their shortduration larval stages are planktonic. Therefore, they are not holozooplankton (defined as animals that are planktonic for their entire life cycle). Further, these embryo and larval life stages are particularly sensitive to non-persistent contaminants (e.g., ammonia) that are commonly present in elutriate water, and may cause toxicity, thus confounding the toxicity assessment of persistent contaminants of concern (e.g., metals and hydrophobic organic compounds). For an extensive discussion of these development toxicity tests in the context and practice of DM evaluations including issues in applying application factors for survival (LC5O) data to development toxicity data (EC5O), see Kennedy et al. (2015).

TOXCITY TESTING USING HOLOZOOPLANKTON: Testing using marine animals that are planktonic for all of their life cycle is needed to satisfy the MPRSA zooplankton requirement. Test species should be relatively sensitive to persistent contaminants of concern but less sensitive to confounding factors, such as handling, physical particle effects and non-persistent contaminants. Table 1a lists candidate marine holozooplankton test species that are commercially available in the United States, and have toxicity test methods at various stages of development (literature published or standardized methods). This species list is not intended to be comprehensive; instead it serves to illustrate that holozooplankton species are available for use in routine testing of DM elutriates. It also prioritizes marine holozooplankton species that are readily commercially available year round, a characteristic that is key to biological testing of DM (USEPA/USACE 1991; 1998). 
Table 1. List of candidate marine holozooplankton test species (a) and epibenthic species (b). While holozooplankton species are generally more relevant for elutriate or water column evaluations, harpacticoid copepods (b) are listed separately since more testing has been conducted in the United States and more test methods are available.

\begin{tabular}{|l|l|l|}
\hline \multicolumn{1}{|c|}{ Taxon } & \multicolumn{1}{|c|}{ Genus } & \multicolumn{1}{c|}{ Species } \\
\hline Calanoid copepods & Acartia & A. tonsa, A. sinjiensis \\
\cline { 2 - 3 } & Pseudodiaptomus & P.pelagicus, P. salina \\
\cline { 2 - 3 } & Parvocalanus & P. crassirostris \\
\hline & & \\
\hline $\begin{array}{l}\text { Harpacticoid } \\
\text { copepod }\end{array}$ & Euterpina* & E. acutifrons \\
\hline & & \\
\hline Cladoceran & Moina & M. salina, M. monogolica \\
\hline \multicolumn{2}{|l|}{ * While harpacticoids are typically benthic, Euterpina is an exception. } \\
\hline Rotifer
\end{tabular}

(b)

\begin{tabular}{|l|l|l|}
\hline Taxon & Genus & Species \\
\hline \multirow{2}{*}{$\begin{array}{l}\text { Harpacticoid } \\
\text { copepods }\end{array}$} & Amphiascus & A.tenuiremis \\
& Nitocra & N. spinipes \\
\cline { 2 - 3 } & Tisbe & T. biminensis \\
\hline
\end{tabular}

STANDARDIZED TESTS FOR HOLOZOOPLANKTON: A standardized 24-hour acute toxicity test method is currently available for freshwater rotifers, which includes an appendix to modify those methods for the estuarine/marine rotifer Brachionus plicatilis (ASTM E1440-91 [2012]). The International Organization for Standardization (ISO) has published a marine test method for B. plicatilis (ISO/FDIS 19820 [2016]). Studies from Europe and Asia have led to efforts to standardize copepod toxicity tests by various organizations, such as the ISO, Organisation for Economic Cooperation and Development (OECD) and ASTM. Much of this work has focused on full life-cycle testing of the epibenthic harpacticoid copepods, rather than the holoplanktonic calanoid copepods; and therefore, has lower relevance to testing toxicity in the water column. For example, a published method exists for a copepod life cycle test using the marine meibenthic copepod Amphiascus tenuiremis (ASTM E2317-04 [2012]) and Nitocra spinipes (ISO/DTS $18220^{1}$ ). Some guidance document validation work (in draft form) did involve the calanoid Acartia tonsa (OECD 2007; ASTM STP667 [1979]) and a full life cycle method (ISO 16778 [2015]) has been published. For acute toxicity, calanoid copepods (Acartia spp.) are listed in ASTM E1850-04 (2012); however, the testing methods are generalized to a large number of freshwater, saltwater, invertebrate and vertebrate test organisms and thus do not provide adequate species specific detail. An acute lethality method has been published for the marine copepods A. tonsa, Tisbe battagliai and N. spinipes (ISO/DIS14669 [1999]), but only A. tonsa is holozooplanktonic. No known standard methods are available for marine

\footnotetext{
${ }^{1}$ International Organization for Standardization (ISO). In review. Water quality - larval development test with the harpacticoid copepod Nitocra spinipes ISO/DTS 18220. International Organization for Standardization: Geneva, Switzerland.
} 
cladocerans (Moina species). Work remains to be done, especially for establishing and standardizing a test method specific to water column elutriate toxicity testing for dredging evaluations conducted under MPRSA. General testing methods from available effluent discharges (USEPA 2002) and dredging evaluations (USEPA/USACE 1991; 1998) may be leveraged. Available feeding and culturing methods may be adapted to ensure food is not a limiting factor in cultures. However, it is appropriate to investigate lower feeding rations, or absence of food, in toxicity testing to reduce interactive effects between food and contaminants of concern.

PUBLISHED RESEARCH USING ALTERNATIVE ZOOPLANKTON: While a few standard test methods for marine holozooplankton are currently available (above section), greater culturing and acute toxicity testing methods are available in the published literature for certain species of marine copepods, cladocerans and rotifers. Most studies found in this review on the use of marine holozooplankton (e.g., copepods, cladocerans, rotifers) in toxicity testing were conducted outside the United States. However, many conspecifics reside in the coastal waters of the United States and therefore testing of these organisms as representative zooplankton species has high relevance. Researchers have previously described some marine copepod culturing methods scaled down from aquaculture for ecotoxicology testing (APHA 1989; Hall et al. 1997; Medina and Barata 2004; Gorbe et al. 2012; ISO/DIS14669 (1999). Various culturing densities were recommended, ranging from 250 to 1000 individuals per liter (APHA 1999; Medina and Barata 2004). Copepods reproduce sexually, with an assumed sex ratio of approximately 1:1 (Kusk and Petersen 1997). Feeding rations described in the literature range from simple 1:1 algae mixtures, such as Isochrysis galbana and Rhinomonas reticulate (Medina et al. 2002; Medina and Barata 2004), to more complex algae mixtures of Skeletonema costatum, Thalassiosira pseudonana, I. galbana, R. baltica (APHA 1999) or I. galbana, Tetraselmis suecica, and $R$. reticulate (Gorbe et al. 2012). While most copepod aquaculture and testing has been done in natural seawater, Kusk and Wollenberger (1999) provided data suggesting culture and testing of $A$. tonsa in artificial seawater is viable. Acute toxicity testing methods (48 to 96 hours) have been conducted and described in the literature for the marine calanoid copepods A. tonsa (Kusk and Petersen 1997; Kusk and Wollenberger 1999; Sverdrup et al. 2002; Medina et al. 2002; Gorbe et al. 2012; Bielmyer et al. 2006), A. sinjiensis (Rose et al. 2006; Gissi et al. 2013), Pseudodiaptomus coronatus (Hauch et al. 1980), Pseudodiaptomus marinus (Huang et al. 2006) and E. affinis (Hall et al. 1997). However, these test descriptions do not provide all of the details necessary for adapting the tests for use with DM elutriates. Feeding may be required during acute toxicity testing (e.g., Hauch et al. 1980), but this may result in interactions with contaminants of concern. Considerably more work has been conducted on the epibenthic harpacticoid copepods (e.g., Verriopoulos and Dimas 1988; Bechmann 1994; see also associated OECD 2007, ASTM and ISO standard methods).

Non-standardized culturing and acute toxicity testing methods for the marine cladoceran Moina monogolica have been described in the literature (He et al. 2001; Wang et al. 2007a; Wang et al. 2007b; Wang et al. 2009; Wang et al. 2010). However, selection of the test species and establishment of successful culture methods has been more elusive compared with to work with copepods (van Dam et al. 2008). These cladocerans reproduce 
parthenogenetically, consume commercially available algae (e.g., Chlorella spp.), have a wide salinity tolerance (He et al. 2001) and can be cultured in synthetic seawater (Wang et al. 2010). Feeding rations have ranged from $2.5 \times 10^{3}$ to $3 \times 10^{6}$ cells $/ \mathrm{mL}$, while keeping adult cladoceran density below 50 individuals per liter (Wang et al. 2007a; Wang et al. 2007b; Wang et al. 2010). Substantially less culturing and toxicity testing information is available for Moina species relative to copepods, although Moina spp. offer advantages of asexual reproduction and can be tested for 48-hours in absence of food.

Culturing and testing methods (48-hour) have also been published for rotifers, particularly Brachionus plicatilis (Theilacker and McMaster 1971; Arnold et al. 2010a). This species is widely distributed throughout the world, very sensitive to metals such as copper, amenable for culture in artificial seawater (wide salinity range) and does not require feeding (for at least 80 hours) during acute testing (Arnold et al. 2010a). These authors increased the exposure duration from the 24-hour duration recommended in the ASTM method to enhance the sensitivity of endpoint response (e.g., decrease in copper $\mathrm{LC}_{50} \mathrm{O}$ from to 68 to $10 \mu \mathrm{g} / \mathrm{L})$.

SENSITIVITY TO METALS: It is desirable that zooplankton test species be highly sensitive to persistent contaminants of concern. Marine copepods have a demonstrated relatively high sensitivity to metals, organometals, organic compounds and surfactants compared to other species (van Dam et al. 2008). Generally, calanoid copepods appear more sensitive to metals relative to harpacticoid copepods (Wang et al. 2007b). Rose et al. (2006) reported that a subtropical species of Acartia was one of the most sensitive species to copper in a species sensitivity distribution. Acartia was also more sensitive than bacteria, microalgae, urchins, oysters, prawn and fish (Kusk and Petersen 1997; Gissi et al. 2013). Moina is reported to be highly sensitive to metals (Garcia-Garcia et al. 2006; Wang et al. 2009). There is some evidence that $M$. monogolica is more sensitive to copper than harpacticoid copepods (i.e., Tigriopus spp.) and calanoid copepods (Pseudodiatomus coronatus, Tisbe holothuriae) but more tolerant than other calanoids (Eurtemora affinis, Acartia spp.) (Wang et al. 2007b). Arnold et al. (2010b) reported that an acute E. affinis test was not as sensitive to copper as echinoderm and mussel embryo development tests. The rotifer B. plicatilis was reported to be one of the most sensitive marine organisms to copper (Arnold et al. 2010a). A non-comprehensive summary of copper toxicity reference values for zooplankton species is provided in Table 2.

CONCLUSIONS AND PATH FORWARD: While acute echinoderm and bivalve embryo development toxicity tests are currently used to meet the zooplankton testing requirement for elutriate toxicity tests in some regions conducted under MPRSA dredging evaluations, a diversity of other true holozooplankton species have been identified herein (Table 1) that meet MPRSA zooplankton requirements. Standardized test methods (ASTM, ISO) exist for harpacticoid copepods; however, those copepod species are epibenthic and may be less appropriate for water column evaluations of DM. Standardized tests are also available for holozooplanktonic calanoid copepods (ISO) and a modification of a freshwater rotifer method is available (ASTM) for use with marine species. Marine cladocerans of the genus Moina are also good candidates for further method development. Further work is needed to validate these methods for the elutriate toxicity tests that are used in water column 


\section{ERDC TN-DOER-R24}

September 2016

evaluations of DM. Towards that end, future research at ERDC will select candidate holozooplankton species (Table 1a), validate proposed culturing, feeding, handling, and test conditions (Table 3) and determine relative sensitivity to metals and ammonia. The impacts of temperature and presence of food on toxicity will be considered. Ultimately, the testing development data and methods will be published in the peer reviewed literature and validated as test methods specific to elutriate toxicity tests for inclusion in future dredging evaluation guidance manuals.

Table 2. Sensitivity of select marine zooplankton to copper and ammonia.

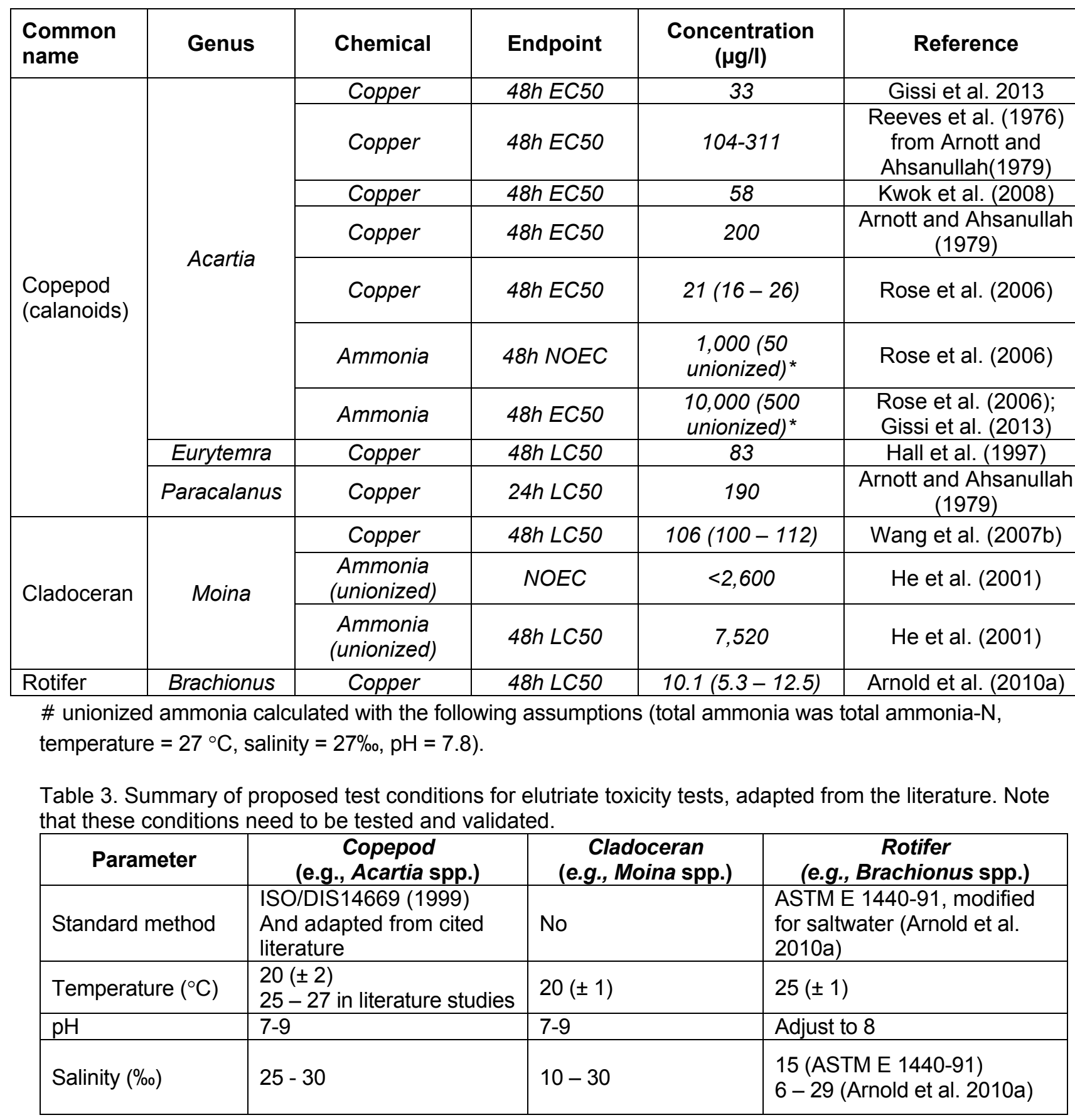




\begin{tabular}{|l|l|l|l|}
\hline \multicolumn{1}{|c|}{ Parameter } & \multicolumn{1}{c|}{$\begin{array}{c}\text { Copepod } \\
\text { (e.g., Acartia spp.) }\end{array}$} & $\begin{array}{c}\text { Cladoceran } \\
\text { (e.g., Moina spp.) }\end{array}$ & \multicolumn{1}{c|}{$\begin{array}{c}\text { Rotifer } \\
\text { (e.g., Brachionus spp.) }\end{array}$} \\
\hline Duration (hours) & 48 & 48 & $\begin{array}{l}24 \\
48 \text { (Arnold et al. 2010a) }\end{array}$ \\
\hline Age & Adults / sub-adults & $<24$ hours & $\begin{array}{l}0-2 \text { hours } \\
0-4 \text { hours (Arnold et al. } \\
2010 a)\end{array}$ \\
\hline No organisms/ rep & 5 & 5 to 10 & 10 \\
\hline $\begin{array}{l}\text { No. reps } \\
\text { (modified for } \\
\text { elutriate testing) }\end{array}$ & 5 & 5 & 5 \\
\hline $\begin{array}{l}\text { Total } \\
\text { organisms/concent } \\
\text { ration }\end{array}$ & 25 (minimum) & 25 to 50 & 50 \\
\hline Feeding & $\begin{array}{l}2 \text { hours prior to test. No } \\
\text { feeding during test } \\
\text { (preferred) or at } 0 \text { hours if } \\
\text { required for survival }\end{array}$ & $\begin{array}{l}2 \text { hours prior to test; } \\
\text { none during test }\end{array}$ & Prior to test; none during test \\
\hline Ancration & $\begin{array}{l}\text { Only if needed to maintain } \\
\text { oxygen }\end{array}$ & $\begin{array}{l}\text { Only if needed to } \\
\text { maintain acceptable } \\
\text { dissolved oxygen }\end{array}$ & $\begin{array}{l}\text { Only if needed to maintain } \\
\text { acceptable dissolved oxygen }\end{array}$ \\
\hline $\begin{array}{l}\text { Assessment } \\
\text { endpoint }\end{array}$ & Immobilization & $\begin{array}{l}\text { Survival, } \\
\text { immobilization }\end{array}$ & $\begin{array}{l}\text { Mortality (lack of movement } \\
\text { for } 5 \text { seconds) }\end{array}$ \\
\hline Test acceptability & $\geq 90 \%$ in control & $\begin{array}{l}\geq 80-90 \% \text { in control } \\
\geq 90 \% \text { in control }\end{array}$ & \\
\hline
\end{tabular}

ADDITIONAL INFORMATION: This Technical Note was written under the Dredging Operations and Environmental Research (DOER) program by Alan Kennedy (Alan.J.Kennedy@usace.army.mil, Tel: 601-634-3344, Fax: 601-634-2263), Guilherme R. Lotufo (Guilherme.Lotufo@usace.army.mil, Tel: 601-634-4103, Fax: 601-634-2263), Jennifer Laird (Jennifer.G.Laird@usace.army.mil, Tel: 601-634-2554, Fax: 601-634-2263) and J. Daniel Farrar (Daniel.Farrar@usace.army.mil, Tel: 601-634-2118, Fax: 601-6342263) of the U.S. Army Engineer Research and Development Center (ERDC), Environmental Laboratory (EL).

This DOER Technical Note should be referenced as follows:

Kennedy, A. J., G. R. Lotufo, J. G. Laird, and J. D. Farrar. 2016. Dredged Material Evaluations: Review of Zooplankton Toxicity Test Methods for Marine Water Quality Evaluations. DOER Technical Notes Collection. ERDC TN-DOER-R24. U.S. Army Engineer R\&D Center, Vicksburg, MS.

This DOER-TN and files for the examples may be downloaded from http://chl.wes.army.mil/library/publications/chetn/and http://xmswiki.com/. 


\section{REFERENCES}

American Society for Testing and Materials (ASTM). 2004. Standard guide for conducting static acute toxicity tests with echinoid embryos. Standard E1563-98(2004)e1. West Conshohocken, PA: ASTM International.

American Society for Testing and Materials (ASTM). 2004. Standard guide for conducting static acute toxicity tests starting with embryos of four species of saltwater bivalve molluscs. Standard E72498, West Conshohocken, PA: ASTM International.

American Society for the Testing of Materials International (ASTM). 2012. Standard guide for acute toxicity test with the rotifer Brachionus. Designation E 1440-91. Annual book of ASTM standards, vol 11.05. West Conshohocken, PA: ASTM International pp 830-837.

American Society for Testing and Materials (ASTM). 2012. Standard guide for conducting renewal microplate-based life-cycle toxicity tests with a marine meiobenthic copepod. Designation E231704. West Conshohocken, PA: ASTM International.

American Society for Testing and Materials (ASTM). 2012. Standard guide for selection of resident species as test organisms for aquatic and sediment toxicity tests. Designation: E1850 - 04.West Conshohocken, PA: ASTM International.

American Society for Testing and Materials (ASTM). 1979. A chronic toxicity test with the marine copepod Acartia tonsa. ASTM STP667, West Conshohocken, PA: ASTM International.

American Public Health Association (APHA). 1999. Standard methods for the examination of water and waste water. 17th ed. Washington, DC: APHA.

Arnold, W. R., R. L. Diamond, and D. S. Smith. 2010a. The effects of salinity, pH, and dissolved organic matter on acute copper toxicity to the rotifer, Branchionus plicatilis ("L" strain). Archives of Environmental Contamination and Toxicology 59:225-234.

Arnold, W. R., J. S. Cotsifas, R. S. Ogle, S. G. S. DePalma, and D. S. Smith. 2010b. A comparison of the copper sensitivity of six invertebrate species in ambient salt water of varying dissolved organic matter concentrations. Environmental Toxicology and Chemistry 29:311-319.

Arnott, G. H., and M. Ahsanullah. 1979. Acute toxicity of copper, cadmium and zinc to three species of marine copepod. Australian Journal of Marine and Freshwater Research 30: 63-71.

Bechmann, R. K. 1994. Use of life tables and LC50 tests to evaluate chronic and acute toxicity effects of copper on the marine copepod Tisbe furcata (Baird). Environmental Toxicology and Chemistry 13:1509-1517.

Bielmyer, G. K., M. Grosell, and K. V. Brix. 2006. Toxicity of silver, zinc, copper, and nickel to the copepod Acartia tonsa exposed via phytoplankton diet. Environmental Science and Technology 40:20632068.

Garcia-Garcia G., S. Nandini, and S. S. S. Sarma. 2006. Turbidity mitigates lead toxicity to cladocerans (Cladocera). Ecotoxicology 15:425-436.

Gissi F., M. T. Binet, and M. S. Adams. 2013. Acute toxicity testing with the tropical copepod Acartia sinjiensis: optimzation and application. Ecotoxicology and Environmental Safety 97:86-93. 
Gorbe G., M. Invidia, F. Savorelli, O. Faraponova, E. Glacco, M. Cigar, I. Buttino, T. Leoni, E. Practo, I. Lacchetti, and S. Sei. 2012. Standardized methods for acute and semichronic toxicity tests with the copepod Acartia tonsa. Environmental Toxicology and Chemistry 31:2023-2028.

Hall L. W., R. D. Anderson, J. V. Kilian, B. I. Lewis, and K. Traexler. 1997. Acute and chronic toxicity of copper to the estuarine copepod Eurytemora affinis: Influence of organic complexation and speciation. Chemosphere 35:1567-1597.

Hauch R. G., D. R. Norris, and R. H. Pierce. 1980. Acute and chronic toxicity of sodium pentachlorophenate to the copepod, Pseudodiaptomus coronatus. Archives of Environmental Contamination and Toxicology 25:562-568.

He Z. H., J. G. Qin, Y. Wang, H. Jiang, and Z. Wen. 2001. Biology of Moina mongolica (Moinidae, Cladocera) and perspective as live food for marine fish larvae: A review. Hydrobiologia 457:2537.

Huang Y., L. Zhu, and G. Liu. 2006. The effects of bis(tributyltin) oxide on the development, reproduction and sex ratio of calanoid copepod Pseudodiaptomus marinus. Estuarine Coastal and Shelf Science 69:147-152.

International Organization for Standardization (ISO). 1999. Water quality - determination of acute lethal toxicity to marine copepods (Copepoda, Crustacea). Draft International Standard ISO/DIS14669. International Organization for Standardization, Geneva, Switzerland.

International Organization for Standardization (ISO). 2016. Water quality - determination of the acute toxicity to the marine rotifer Brachionus plicatilis. ISO/FDIS 19820. International Organization for Standardization, Geneva, Switzerland.

International Organization for Standardization (ISO). 2015. Water quality - calanoid copepod early-life stage test with Acartia tonsa. ISO 16778:2015. International Organization for Standardization, Geneva, Switzerland.

Kennedy, A J., G. R. Lotufo, and J. A. Steevens. 2015. Review of dredged elutriate application factors: relevance to acute-to-chronic protection, contaminant, and endpoint specificity. ERDC/EL TR15-10. Vicksburg, MS: U.S. Army Engineer Research and Development Center.

Kusk, K. O., and L. Wollenberger. 1999. Fully defined salt water medium for cultivation of and toxicity testing with the marine copepod Acartia tonsa. Environmental Toxicology and Chemistry 18(7):1564-1567.

Kusk, K. O., and S. Petersen. 1997. Acute and chronic toxicity of tributyltin and linear alkylbenzene sulfonate to the marine copepod Acartia tonsa. Environmental Toxicology and Chemistry 16:1629-1633.

Limiting Permissible Concentration (LPC) 40 CFR 227.27. 2012. Part 227 - Criteria for the evaluation of permit applications for ocean dumping of materials - subpart G - definitions- section 227.27

Medina, M., C. Barata, T. Telfer, and D. J. Baird. 2002. Age and sex related variation in sensitivity to the pyrethroid cypermethrin in the marine copepod Acartia tonsa Dana. Arch. Environmental Contaminant. Toxicology 42:17-22.

Medina, M., and C. Barata. 2004. Static-renewal culture of Acartia tonsa (Copepoda: Calanoida) for ecotoxicological testing. Aquaculture 229:203-213. 
Organisation for Economic Co-operation and Development (OECD). 2007. Validation report of the full life-cycle test with the harpacticoid copepods Nitocra spinipes and Amphiascus tenuiremis and the calanoid copepod Acartia tonsa - Phase 1. Series on testing and assessment. 79. ENV/JM/ MONO (2007) 26. Brussels, Belgium.

Rose A., A. M. Carruthers, J. Stauber, R. Lim, and S. Blcokwell. 2006. Development of an acute toxicity test with the marine copepod Acartia sinjiensis. Austrialasian Journal of Ecotoxicology 12:73-81.

Sverdrup, L. E., C. S. Fürst, M. Weideborg, E. A. Vik, and J. Stenersen. 2002. Relative sensitivity of one freshwater and two marine acute toxicity tests as determined by testing 30 off shore and chemicals. Chemosphere 46:311-318.

Theilacker G. H., and M. F. McMaster. 1971. Mass culture of the rotifer Brachionus plicatilis and its evaluation as a food for larval anchovies. International Journal on Life in Oceans and Coastal Waters 10:183-188.

United States Environmental Protection Agency (USEPA). 2002. Methods for measuring the acute toxicity of effluents and receiving waters to freshwater and marine organisms, 5 th ed. EPA 821/R-02/012. Office of Water, Washington, DC.

USEPA/USACE. 1991. Evaluation of dredged material proposed for ocean disposal (ocean testing manual). EPA 503/8-91/o01. Washington, DC: U.S. Environmental Protection Agency.

USEPA/USACE. 1998. Evaluation of material proposed for discharge to waters of the US - testing manual (inland testing manual). EPA/823/B-98/o04. Washington, DC: U.S. Environmental Protection Agency.

van Dam R. A., A. J. Harford, M. A. Houston, A. C. Hogan, and A. P. Negri. 2008. Tropical marine toxicity testing in Australia: A review and recommendations. Australasian Journal of Ecotoxicology 14:55-88.

Verriopoulus G., and A. Dimas. 1988. Combined toxicity of copper, cadmium, zinc, lead, nickel and chrome to the copepod Tisbe holothuriae. Bulletin of Environmental Contaminant and Toxicology 41:384.

Wang Z. S., H. N. Kong, and D. Y. Wu. 2007a. Reproductive toxicity of dietary copper to a saltwater cladoceran Moina monogolica Daday. Environmental Toxicology and Chemistry 26:126-131.

Wang Z. S., H. N. Kong, and D. Y. Wu. 2007b. Acute and chronic copper toxicity to a salt water cladoceran Moina monogolica Daday. Archives of Environmental Contamination and Toxicology 53:50-56.

Wang Z. S., C. Yan, and X. Zhang. 2009. Acute and chronic cadmium toxicity to a saltwater cladoceran Moina monogolica Daday and its relative importance. Ecotoxicology 18:47-54.

Wang Z., C. Yan, and R. V. Hyne. 2010. Effects of dietary cadmium exposure on reproduction of saltwater cladoceran Moina monogolica Daday: implications in water quality criteria. Environmental Toxicology and Chemistry 29:365-372.

NOTE: The contents of this technical note are not to be used for advertising, publication, or promotional purposes. Citation of trade names does not constitute an official endorsement or approval of the use of such products. 